\title{
MŁODZIEŻ A WSPÓŁCZESNE KONTROWERSYJNE SEKTY: WYBRANE ZAGADNIENIA
}

\begin{abstract}
Streszczenie
Artykuł podejmuje problem działalności kontrowersyjnych grup kultowych i ich wpływ na młodzież. W pierwszej części opisano i analizowano młodość jako ważny etap rozwoju człowieka. Scharakteryzowano sytuację społeczną w jakiej dorasta młodzież oraz wskazano na najważniejsze potrzeby młodzieży. W dalszej części artykułu przedstawiono podstawowe definicje dotyczące sekt i omówiono sposób ich kontrowersyjnego oddziaływania na społeczeństwo i młodzież. Omówiono przyczyny powstawania sekt i zmienne sprzyjające możliwej ich atrakcyjności. Omówiono również zagadnienie podatności na działanie sekt.

Części końcowa koncentruje się na konieczności organizowania i prowadzenia oddziaływań profilaktycznych i terapeutycznych w kontekście pracy pedagogów, pracowników socjalnych i psychologów
\end{abstract}

Słowa kluczowe: młodzież, sekty, profilaktyka, terapia, społeczeństwo

\section{Wstęp}

Publicznie dyskutowany temat faktycznych i możliwych zagrożenia ze strony sekt budzi zainteresowanie licznych środowisk wychowawczych. Młodzież stanowi uprzywilejowaną grupę docelową dla zróżnicowanych oddziaływań propagandowych ze strony sekt i licznych grup kultowych. Destrukcyjny wpływ złudnych ideologii kontrowersyjnych sekt na młodzież potwierdzają liczne badania z zakresu nauk społecznych (Barker 1997; Nowakowski 2006; Szostak 2001; Zwoliński, 2004). O ile psychologowie koncentrują się głównie na badaniu kontroli umysłu oraz szeroko rozumianej psychomanipulacji, tak pedagodzy w swych analizach sekt 
podejmują głównie kwestie profilaktyki społecznej, oddziaływań edukacyjnych i wychowawczych. Z pewnością, temat wpływu sekt na młodzież jest poznawczo ważny. W sposób szczególny od wielu już lat tematem sekt zainteresowane są środowiska edukacyjne i wychowawcze.

Młodzież jako przedmiot zainteresowania kontrowersyjnych sekt

Stojąca często na egzystencjalnym rozdrożu życia młodzież, stanowi uprzywilejowaną grupę społeczną do której adresowane są werbunkowe akcje kontrowersyjnych sekt. Młodzi, niosą w sobie nieograniczone pokłady życiowych pragnień, jak i nie do końca ukształtowany system oceny wartości, tego co dobre, a co złe, prawdziwe czy złudne, co sprzyja działalności charyzmatycznych siewców wzniosłych ideałów.

Młodość rozumiana jest jako czas odkrywania i wchodzenia w wielki świat nieograniczonych możliwości. Jest to niezwykle istotny czas w życiu każdego człowieka. Rozumiana jest jako przejście od dzieciństwa do dorosłości. Młodość obejmuje również zintensyfikowany rozwój psychofizyczny i społeczny. Jest to czas odkrywania własnego „Ja”, kształtowania się tożsamości, nawiązywania relacji z innymi, kształtowania osobowości i wzmacniania charakteru. Okres młodości to również czas snucia planów na przyszłość, szukania wartości z którymi można byłoby się utożsamić, które wyznaczyłyby główne cele życiowe (Mariański 2007; Łapińska, Żebrowska 1986; Pospiszyl 2000).

Wchodzenie w świat dorosłych stawia młodym liczne wyzwania. Z jednej strony jest to dla nich "fascynujacy czas eksploracji, eksperymentowania, poszukiwania nowych, intensywnych doznan, odkrywania siebie i innych, otwierania się nowych horyzontów myślowych, ksztattowania tożsamości” z drugiej zaś jest czasem „dorastania, dojrzewania do odpowiedzialności, ścierania się przeciwieństw, czas kryzysów oraz uczenia się dorostości” (Biel 2009: 74). Z pewnością, młodość to czas przejściowy, podczas którego młodzi przygotowują się do podjęcia ról dorosłych. Okresowi temu towarzyszą liczne napięcia, często egzystencjalna niepewność, lęk, itp.

Świat, w którym żyje młodzież wymaga od niej odkrycia, akceptacji i interioryzacji określonych wartości. Nie jest to jednak łatwe, i młodzi „potrzebuja pomocy osób dorostych w ukierunkowywaniu ich ku prawdziwym wartościom umożliwiającym petniejsze odnajdywanie sensu i znaczenia życia osobistego oraz spotecznego" (Błasiak 2009: 37). Co więcej, potrzebują zaufanych przewodników, kogoś, kto będzie dla nich autorytetem i wzorem, za którym będą mogli podążać (Obuchowska 2000).

Młodzież szuka na różne sposoby kogoś, kto udzieli jej odpowiedzi na nurtujące ją pytania egzystencjalne i wskaże jej, co jest dobre, a co złe, określi drogę, którą warto podążać w życiu. Wchodząc $\mathrm{w}$ świat dorosłych młodzież na różne sposo- 
by dąży do znalezienia w nim swojego miejsca, wyrobienia własnych poglądów, przekonań i opinii, poszukuje również satysfakcjonujących relacji z innymi oraz możliwości aktywnego zaangażowania się na rzecz innych. Niewątpliwie, jak zauważa słusznie A. Błasiak (2019: 47) współczesna młodzież, wzrastając w epoce ponowoczesności otwarta jest na wszystko, interesuje się wszystkim i wszystkiego jest ciekawa. W ten sposób korzysta „z rynku możliwości” dając się prowadzić w najrozmaitszych kierunkach.

Kontrowersyjne sekty i grupy kultowe umiejętnie wykorzystują egzystencjalne niepokoje młodzieży oraz ich naturalne potrzeby (Gajewski 2016; Nowakowski 2006; Zwoliński 2006). Kreśląc przed młodymi szerokie możliwości realizowania siebie, z powodzeniem rekrutują młodych zaangażowanych adeptów własnych idei.

\section{Sekty. Charakter, sposób działania. Kontrowersje}

W literaturze przedmiotu odnajdujemy wiele definicji sekt, które w zależności od kontekstu nazywa się równie często grupami kultowymi, nowymi ruchami religijnymi czy grupami psychomanipulacyjnymi (Barker 1997; Clarke 2006).

Pojęcie sekta wywodzi się z języka łacińskiego i pochodzi najprawdopodobniej od czasownika sequor, który tłumaczymy: „iść”, „podążać za kims”” lub od czasownika secare: „odcinać”, „oddzielać się” od kogoś lub czegoś. W tym kontekście poprzez sektę rozumie się grupę religijną, która kontestuje grupę macierzystą od której się odłączyła lub grupę, która ślepo podąża za charyzmatycznym liderem. O ile w pierwszym wypadku możemy obserwować opozycyjny charakter sekty względem innej konkretnej religii, tak w drugim, niekoniecznie. Pierwotnie słowo sekta nie posiadało wyłącznie znaczenia pejoratywnego. Ze względu na swój psychomanipulacyjny charakter obecnie sekty kojarzone są z grupami psychomanipulacyjnymi (Barrett 2003; Gajewski, Kosińska 2000; Grzywa 1997).

Badacz sekt i nowych ruchów religijnych Bryan Wilson wskazuje na kilka podstawowych cech kontrowersyjnego kultu, zauważając, że sekta „zmienia catkowicie kontekst dążeń jednostki, aprobując cechy, które zupetnie inaczej oceniane sq w świecie, stwarzając nastrój bezpieczeństwa w stabilnej i uczuciowo powiązanej wspólnocie a także udziela swoim cztonkom gwarancji szczególnej taski boskiej" (Wilson 1961: 354).

Ujmując problem sekt, z perspektywy nauk społecznych, w sposób możliwie całościowy, uwzględniając psychologię ich funkcjonowania, strukturę, jak i sposób pozyskiwania nowych członków, możemy powiedzieć, że sekta to "grupa ludzi, w której możemy wyróżnić konkretna strukture (element formalny), jak i stanowiący ośświatopoglad (element treściowy - religijny lub filozoficzno-religijny), wokót którego i dla którego grupa ta skupia swoich cztonków" (Gajewski 2009: 24; Gajewski 2016). 
Sekta może „stanowić syntezę wielu tradycji filozoficzno-religijnych. W przypadku sekty destrukcyjnej obserwujemy u jej cztonków tzw. syndrom sekty, będący odbiciem niszczacego wptywu grupy na jednostkę w wymiarze duchowym, psychicznym i fizycznym. Sekta destrukcyjna tamie podstawowe prawa cztowieka, stosując szeroko rozumiana psychomanipulację i staje się grupa patologiczno-przestępcza" (Gajewski 2009: 24).

To co charakteryzuje współczesne sekty i zarazem budzi społeczny sprzeciw, to tzw. „fundamentalne oszustwo” kontrolowane przez ich przywódców, którego szeregowi adepci nie są świadomi. Zazwyczaj jest już za późno, na konstruktywne działanie, kiedy szeregowi członkowie za fasadą uśmiechniętych twarzy współwyznawców odkrywają mroczny świat psychicznego uzależnienia, manipulacji, często również przemocy.

\section{Przyczyny powstawania i atrakcyjności grup sektowych}

Istnieje wiele teorii wyjaśniających przyczyny powstawania i atrakcyjności grup sektowych (Grzymała-Moszczyńska 1991; Springer 2000; Zwoliński 2004). Wśród najważniejszych przyczyn wymienia się szeroko rozumiane przemiany społeczno-kulturowe, jak i obszar indywidualnych potrzeb człowieka (Grzymała-Moszczyńska 1991; Nowakowski 2006b). Wiek XIX i XX uznaje się za szczególny czas rozwoju alternatywnych grup religijnych, które „rzuciły wyzwanie” tradycyjnym Kościołom. Wiele z nich deklaruje wręcz swą „areligijność” przedstawiając się jako grupy promujące idee samorozwoju, wartości ekologiczne, humanistyczne czy terapeutyczne. Zdaniem B. Wilsona „Sekty rekrutuja się zasadniczo z cztonków tych zbiorowości, dla których sq one w stanie spetniać bardziej specyficzne funkcje spoteczne. Sekta stuży jako mata grupa odniesienia <zachowań odbiegajacych od normy>, w której jednostka może osiagnać pewien status i prestiż, w której jej zdolności i umiejętności sq oceniane wedtug korzystniejszych kryteriów niż w catym spoteczensstwie" (Wilson 1961: 353).

Do najważniejszych koncepcji wyjaśniających fenomen powstawania sekt literatura przedmiotu zalicza (Bukalski 2006; Doktór 1990; Grzymała-Moszczyńska 1991; Springer 2000):

- Koncepcję relatywnej deprywacji. Wywodzi się ona z psychologii społecznej. Koncepcja ta wymienia trzy typy deprywacji relatywnej: aspiracyjny, kryzysowy i progresywny. Zgodnie z tą koncepcją do ważnych przyczyny powstawania grup kultowych zaliczyć należy deprywację ważnych sfer życia człowieka, które owe grupy starają się wypełniać. Co prawda - jak twierdzą krytycy tej koncepcji - deprywacja potrzeb może być ważnym czynnikiem ułatwiającym powstawanie i rozwój grup kultowych, ale trudno tym argumentem uzasadnić, że jest tego jedyną przyczyną. 
- Koncepcję „ruchów rewitalizacyjnych”. Zgodnie z tą teorią, należy łączyć rozwój grup sektowych z doświadczeniem człowieka w jego relacji do społeczeństwa, które postrzegane jest jako system zdezorganizowany. Samo pojęcie rewitalizacji obejmuje desygnaty tak zróżnicowanych kategorii, jak: „ruchy odrodzenia (spotecznego, kulturowego, religijnego), reformacyjne, wspólnoty utopijne, rewolucje, ruchy masowe, ruchy spoteczne, czy też ruchy charyzmatyczne" (Bielska 2015). U podstaw rewitalizacji znajduje się więc zazwyczaj silne dążenie do zmiany. Człowiek przeżywając istotne egzystencjalnie wydarzenia, takie jak kataklizmy, klęski żywiołowe, wojenne, doświadcza poczucia zagrożenia swojego życia bądź dezorganizacji społecznej i rodzinnej. Rewitalizacja w tym kontekście jawi się jako jedyna droga wyjścia z takiego stanu.

- Koncepcję „rytuałów przejścia”. Teoria nawiązuje do procesu przechodzenia z jednej fazy życia do drugiej w biegu życia. Szczególnym momentem w rozwoju jest okres dorastania młodego człowieka, w którym przeżywa on wiele trudności i różnych konfliktów. Młodość to czas kształtowania własnej tożsamości, poszukiwanie wzorców, interioryzacja wartości życiowych, określanie siebie w kontekście relacji społecznych. Zwraca się uwagę na ważny moment przejścia z pozycji zależności względem rodziców i wejścia w świat osób dorosłych. Grupy kultowe zdają się umiejętnie wchodzić w sytuacje przejścia, zagospodarowując przestrzeń potrzeb i społecznych oczekiwań młodego człowieka.

- Koncepcję podkreślającą rolę czynników poznawczych. W ludzką psychikę wpisana jest silna potrzeba racjonalnego przeżywania siebie i otaczającego go świata. Wraz z rozwojem psychologii poznawczo-behawioralnej podkreśla się znaczenie umysłowych procesów poznawczych, którymi legitymizuje się współczesny człowiek. Wkraczająca w dorosłe życie młodzież, w sposób szczególny domaga się odpowiedzi na przeróżne pytania dotyczące porządku świata, sensu istnienia, religii, wartości, itp. Świat w którym dorastają młodzi, zdaje się zatracać swą jednoznaczność, wszelkie wartości ulegają zrelatywizowaniu, a upadek autorytetów potęguje poczucie zagubienia. Grupy kultowe wraz ze swymi często maksymalnie uproszczonymi doktrynami oferują młodym proste i pozornie klarowne odpowiedzi na egzystencjalnie skomplikowane pytania.

- Koncepcję nawiązującą do psychopatologii w odniesieniu do jednostki. Teoria ta odwołuje się do psychicznej kondycji współczesnego człowieka. Problemy zdrowia psychicznego dotykają ludzi pochodzących z różnych warstw społecznych. Wśród uczestników wielu kontrowersyjnych sekt można wskazać grupę osób, których stan zdrowia psychicznego budzi poważne zastrzeżenia. Wśród nich znajdują się osoby z zaburzoną osobowością, zaburzeniami emocjonalnymi i behawioralnymi. Udział w kontrowersyjnym kulcie dla tego typu osób staje się sposobem na radzenie sobie z własnymi niedomaganiami. Silna zależność od liderów tychże grup, 
wyraźna kontrola myślenia i zachowania paradoksalnie w pewnych przypadkach może jawić się jako czynnik terapeutyczny.

- Koncepcję Johna Loflanda. Koncepcja ta wskazuje na szereg warunków, które muszą zostać spełnione w sposób równoczesny, aby móc uznać, że dana jednostka w pełni włączyła się w daną grupę kultową. Wśród najważniejszych czynników predysponujących wejście w sektę odnajdujemy: poszukiwanie prawdy religijnej pozwalającej na pozytywne rozwiązanie problemów życiowych przyzywanych przez jednostkę, poczucie napięcia, którego rozładowanie możliwe będzie w napotkanej grupie kultowej. Model Loflanda podkreśla sytuację zewnętrzną, społeczną, kulturową uwzględniając złożone mechanizmy rekrutacji jakie stosują kontrowersyjne sekty.

- Koncepcję „narcyzmu”. Zgodnie z teorią, wywodzącą się z psychoanalizy podkreśla się znaczenie i rolę pierwotnego narcyzmu, a także dążenia człowieka do zaspokajania potrzeb. Zgodnie z tą teorią nierozwiązane konflikty i związane z nimi potrzeby, w tym przede wszystkim zależności sięgają okresu wczesnego dzieciństwa. Narcyzm posiada silne powiązanie z licznymi potrzebami, które w różnym stopniu od okresu dzieciństwa zostają przepracowane. Ruchy kultowe zgodnie z teorią odpowiadają na potrzeby ludzkie, stąd ich działalność jest akceptowana lub wręcz pożądana.

\section{Czynniki ryzyka a podatność młodzieży na działanie sekt}

Istnieje wiele powodów dla których młodzi interesują się kontrowersyjnymi sektami (Frankowiak 2016; Taran 2000). Motywacje są różne, i zależą od wielu czynników, które nie zawsze są do końca przez młodzież uświadomione. Wśród najważniejszych proponuję uwzględnić 1) predyspozycje indywidualne (osobowość, temperament), 2) predykatory związane $\mathbf{z}$ rodziną pochodzenia, 3) atrakcyjność sekt i ich ofert oraz 4) sytuacyjny kontekst spotkania młodego człowieka z emisariuszem danej sekty a także 5) kontekst społeczno-kulturowy.

1) Predyspozycje indywidualne (osobowość, temperament).

Jak wynika z doświadczeń klinicystów, oraz badań nad podatnością na zwerbowanie przez sektę, osoby o silnej osobowości i temperamencie są bardziej odporne na propagandę ze strony sekt (Anthony, Robbins 2004; Kuncewicz 2005; Ward 2000). Można się więc spodziewać, że młodzież o silnej osobowości legitymuje się silniejszym krytycyzmem względem utopijnych idei i naiwnych recept na lepsze udane życie, itp. Osoby takie nawiązują i utrzymują zdrowe i twórcze relacje z rówieśnikami, lepiej radzą sobie z sytuacjami stresu, posiadają spójny i koherentny 
obraz świata i swojego w nim miejsca. Sekty zdają się docierać z własną propagandą głównie do ludzi o słabej psychice, często życiowo zagubionych, niepewnych, łatwowiernych i mało krytycznych. Młodzież o słabej strukturze psychicznej w sposób mniej krytyczny zdaje się na prowadzenie przez charyzmatyczne autorytety, w których upatruje wzmocnienia dla często chwiejnych i sprzecznych emocji, pragnień i oczekiwań.

\section{2) Rodzina pochodzenia}

Rodzina pochodzenia stanowi pierwsze i podstawowe środowisko rozwoju dzieci i młodzieży. Rodziny o zdrowej i funkcjonalnej strukturze sprzyjają prawidłowemu rozwojowi młodego pokolenia. Wszelkie dysfunkcje w obrębie ich funkcjonowania oraz patologiczne schematy funkcjonowania stanowią istotny czynnik ryzyka dla możliwości uwikłania się dzieci i młodzieży w działanie kontrowersyjnej grupy kultowej. Rodziny nierealizujące podstawowych funkcji opiekuńczych i wychowawczych narażają młodzież na ryzyko szukania ciepła domowego w szeregach kontrowersyjnych sekt, które jawią się jako interesujące alternatywy dla dysfunkcyjnych lub patologicznych rodzin (Bukalski 2006). Zaburzenie granic wewnątrzrodzinnych, dysfunkcyjna dystrybucja praw i obowiązków, nadmierny rygoryzm lub rodzinne splątanie to kolejne czynniki ryzyka.

\section{3) Atrakcyjność samych sekt i ich ofert}

Bez wątpienia sukces sekt wynika z ich atrakcyjności, którą mamią młodych ludzi. Należy zauważyć, że emisariusze sekt szkoleni są jak docierać do młodzieży ze swoją ofertą, i co robić, aby była ona ciekawa i przekonująca (Gajewski 2016). Niekwestionowany rozwój Internetu, mediów społecznościowych, w sposób szczególny sprzyja sektom w dotarciu do młodego człowieka. Idee głoszone przez liderów publikowane są w olbrzymich nakładach i dystrybuowane osobiście przez emisariuszy w postaci ulotek, broszur, książek, itp. Ponadto sekty organizują rozmaite koncerty, spotkania, akcje charytatywne. Niebezpieczna ideologia opakowywana jest w lekkie niezobowiązujące nośne hasła bliskie młodym ludziom. Faktem jest, że wiele kontrowersyjnych grup kultowych organizuje pozornie lub faktycznie pozytywne i wartościowe przedsięwzięcia o charakterze propagandowym. Walka z ubóstwem, idee ekologiczne, zabieganie o pokój na świecie brzmią atrakcyjnie, co przyciąga zainteresowanie młodzieży.

\section{4) Sytuacyjny kontekst spotkania}

Nie bez znaczenia dla procesu rekrutacji do sekty ma sytuacyjny kontekst spotkania. Ze strony młodego człowieka wszystko może wydawać się przypadkowe, ze strony sekty będzie miało charakter ściśle zaplanowany i odbywać się będzie 
wedle zaplanowanego scenariusza. Istnieje również kontekst sytuacyjny, który leży poza kontrolą sekty. Nie wszystko musi być kontrolowane i zaplanowane. Sytuacją taką może być przypadkowa rozmowa, spotkanie w autobusie, w pociągu czy na przystanku (Nowakowski 2006a). Emisariusze wielu sekt uczeni są by świadczyć na rzecz grupy „zawsze i wszędzie”. Nie bez znaczenia na możliwy proces rozpoczęcia procesu wejścia w sektę ma chwilowa sytuacja nastroju lub szerszy kontekst egzystencjalny danej osoby. Choroba lub śmierć bliskiej osoby może stać się zmienną sytuacyjną, która będzie osłabiać myślenie krytyczne i równocześnie wspierać zainteresowanie ofertą sekty nawiązującą do sytuacji egzystencjalnej danej osoby.

\section{5) Kontekst społeczno - kulturowy}

Podatność młodzieży na oddziaływania grup sektowych warunkowana jest w znaczny sposób przez kontekst kulturowy i społeczny. Istnieją takie środowiska, w których dominuje myślenie pluralistyczne względem aktywności religijnej ich członków. Oznacza to występowanie większej tolerancyjności na odmienność religijną. W tym kontekście wielość grup religijnych nie stanowi społecznego problemu, jest wręcz akceptowana i uznawana za objaw zdrowego funkcjonowania społeczności. Istnieją również takie środowiska, w których odnotowuje się silną dominację jednej lub dwóch głównych religii, a wszelkie przejawy braku religijnej ortodoksji narażone są na społeczną dezaprobatę. Myślący religijnie „inaczej” są społecznie naznaczani, uznani za obce i niepożądane ciało w zdrowej tkance społecznej. W tego typu układach społecznych przynależność do grup kultowych jest ukrywana, w obawie przed ujawnieniem i społecznym wykluczeniem jej członków.

\section{Oddziaływania profilaktyczne i terapia - wskazania dla pedagogów, pracowników socjalnych i psychologów}

Fenomen popularności sekt wiąże się głównie z problemem zagubienia młodzieży w świecie, który jawi się często jako miejsce sprzecznych wartości, przestrzeń rywalizacji, osamotnienia, przemocy, zerwanych relacji, niepewności, na co wskazuje literatura przedmiotu (Białowąs 2005; Cekiera 2005; Daroszewski 2005; Libiszowska-Żółtkowska 2005).

Profilaktykę w obszarze działania kontrowersyjnych sekt należy traktować w sposób wieloaspektowy, zarówno jako interwencję korygującą niedostatki wychowania oraz jako ograniczenie i eliminowanie czynników ryzyka, przy równoczesnej aktywizacji i wzmacnianiu czynników chroniących. Podejmując się organizowania wszelkich działań profilaktycznych i terapeutycznych względem młodzieży, należy uwzględniać złożony kontekst społeczny, w którym funkcjonuje młodzież. 
Projektując szczegółowe rozwiązania należy uwzględniać również cechy osobowościowe i temperamentalne.

Młodość to taka kategoria wiekowa, która jest okresem przejściowym pomiędzy dzieciństwem a dorosłością. To szczególny czas, kiedy młody człowiek nie jest już dzieckiem i jeszcze nie jest dorosłym (Dybowska 2009). Młodość to czas burzliwego „rozstawania się z dzieciństwem i wkraczania w nowy ważny etap rozwojowy, który stwarza szanse dla człowieka, ale i obfituje w różne zagrożenia, często ze skutkami na całe życie, wpływającymi na dalsze losy jednostki, a często i jej najbliższej rodziny" (tamże). Zagrożenie ze strony sekt jest całkiem realne dla wieku dorastania. W sposób mistrzowski oferty sekt wpisują się w egzystencjalne potrzeby młodzieży. Uzasadnionymi są więc wszelkie przedsięwzięcia o charakterze profilaktycznym w zakresie zapobiegania oddziaływania sekt na dzieci i młodzież (Frankowiak 2016; Gaś 2006; Szymańska 2000).

Czy potrzebna jest jakaś specjalna formuła dla tych oddziaływań? Z pewnością oddziaływania profilaktyczne winny koncentrować się na dostarczaniu dzieciom i młodzieży, również ich rodzinom i opiekunom, rzetelnych informacji o zagrożeniach ze strony sekt i kontrowersyjnych grup kultowych (Coates 2011). Nie bez znaczenia dla efektywności posunięć profilaktycznych będą miały wszelkie oddziaływania zmierzające do wzmacniania wewnętrznych psychologicznych zasobów młodzieży (Gajewski 2009; Frankowiak 2016; Szymańska 2000). Wsparcie rodzinne i instytucjonalne (szkoła) odgrywać będzie w tym zakresie istotną rolę. Co więcej, zarówno pedagodzy szkolni, jak i pracownicy socjalni, kuratorzy, psychologowie winni w zakresie przeciwdziałania sektom mieć możliwość odbywania odpowiednich szkoleń, superwizji, i wsparcia ze strony ekspertów oraz instytucji na co dzień zajmujących się problematyką sekt i nowych ruchów religijnych.

Interwencja w zakresie sekt w zależności od sytuacji i wynikającej z niej potrzeb może przybrać formę interwencji kryzysowej, mediacji, counselingu lub psychoterapii. Jej celem powinna być pomoc młodemu człowiekowi „w uzyskaniu możliwie szerokiej kontroli nad własnym życiem oraz wzmocnienie procesu jej samorozwoju poprzez odcięcie się od osób i instytucji, które ograniczają jej taką możliwość" (Gajewski 2011). Praca z osobami uwikłanymi w sekty (dotyczy dzieci, młodzieży i dorosłych) i ich rodzinami przypomina czasami negocjacje.

Niepożądanym, a wręcz szkodliwym jest myślenie o sektach w kategoriach czysto religijnych. Wiele kontrowersyjnych sekt działa w obszarze zupełnie pozareligijnym, mamiąc młodzież ofertami szybkiego rozwoju, możliwością doświadczenia odmiennych stanów świadomości, usprawniania pracy mózgu, oczyszczania umysłu, relaksacji czy możliwości wyjazdu do egzotycznych krajów, nawiązywania nowych międzynarodowych kontaktów, otrzymania wysoko płatnej pracy itp. 


\section{Bibliografia:}

Anthony, D., Robbins, T. (2004). "Conversion and 'brainwashing' in new religious movements". W: The Oxford handbook of new religious movements, Edited by: Lewis, JR. 317-332. Oxford.

Barker, E. (1997). Nowe ruchy religijne, Kraków.

Barrett, D.V. (2003). The New Believers: Sects, 'Cults' and Alternative Religions. Cassell.

Białowąs, A. (2005). O recepcji nowych treści religijnych w świadomości Polaków, SiF 2005, nr 26-27, s. 13-15.

Biel, K. (2009). Dylematy mtodzieży czyli ponowoczesne kroczenie ku dorostości. W: Młodzież wobec ponowoczesności, pod red. M. Duda, Kraków.

Bielska, E. (2015). Ruch społeczny jako czynnik rewitalizacji: analiza w kontekście założeń pedagogiki społecznej, Chowannna 1, 19-29.

Błasiak, A. (2009). Młodzież wobec aksjologicznych dylematów wspótczesności. W: Młodzież wobec ponowoczesności, pod red. M. Duda, Kraków.

Bukalski, S. (2006-2007). Rodzina w perspektywie oddziaływania grup kultowych, Analecta Cracoviensia, 38-39 s. 89-106.

Cekiera, C. (2005). Profilaktyka wobec destrukcyjnej dziatalności sekt. W: W. Nowak, S. Ropiak (red.), Sekty jako wyzwanie społeczne i religijne, Olsztyn, s. 89-99.

Clarke, P. (2006). New Religions in Global Perspective, Abingdon: Routledge.

Coates, D. (2011). Counselling former members of charismatic groups: considering pre-involvement variables, reasons for joining the group and corresponding values, Mental Health, Religion \& Culture, 14:3, 191-207.

Daroszewski, G. (2005). Kto może stać się ofiarą sekty? Jak można pomóc tym ofiarom?, Edukacja dla Bezpieczeństwa 1, s. 57-62.

Dybowska, E. (2009). Wychowawcze towarzyszenie mtodym ludziom inspirowane pedagogika ignacjańska. W: Młodzież wobec ponowoczesności, pod red. M. Duda, Kraków.

Frankowiak, J.K. (2016). Mtodzież a sekty: udziat licealistów w programie profilaktycznym w kontekście podatności na dziatania grup psychomanipulacyjnych, Olsztyn.

Gajewski, M. (2016). Fatszywi Nauczyciele. Sekty Dzisiaj, Kraków.

Gajewski, M., Kosińska, E. (2000). Sekty - religijny supermarket. Krótki poradnik psychologiczny, Kraków.

Gajewski, M. (2009). Sekty i nowe ruchy religijne, Kraków.

Gajewski, M. (red.) (2011). Kontrowersyjne grupy kultowe i sekty. Analiza psychologiczna i prawna, Kraków.

Gaś, Z.B. (2006). Profilaktyka w szkole, Warszawa. 
Grzymała-Moszczyńska, H. (1991). Psychologia religii. Wybrane zagadnienia, Kraków.

Grzywa, A. (1997). Manipulacja. Mechanizmy psychologiczne, Kraśnik.

Kuncewicz, D. (2005). Kontrowersyjne grupy religijne. Psychologiczne aspekty przynależności, Tychy.

Libiszowska-Żółtkowska, M. (2005). Motywy przystępowania do nowych ruchów religijnych. W: W. Nowak, S. Ropiak (red.), Sekty jako wyzwanie spoteczne i religijne, Olsztyn, s. 100-108.

Łapińska, R., Żebrowska, M. (1986). Wiek dorastania. W: Psychologia rozwojowa dzieci i mtodzieży, red. M. Żebrowska, Warszawa, s. 664-796.

Mariański, J. (2007). Przedmowa. W: Problemy wspótczesnej mtodzieży w ujęciu nauk spotecznych, red. F. W. Wawro, Lublin.

Nowakowski, P.T. (2006a). Co każdy powinien wiedzieć o sektach. Materiaty pomocnicze, Kraków.

Nowakowski, P.T. (2006b). Dziatalność werbunkowa sekt (1). Szkota na celowniku, Magazyn Szkolny. Pismo Kuratorium Oświaty w Katowicach 7, s. 17.

Obuchowska, I. (2000). Adolescencja. W: Psychologia rozwoju człowieka. Charakterystyka okresów życia człowieka. Tom 2, red. B. Harwas-Napierała, J. Trempała, Warszawa, s. 163-201.

Pospiszyl, K. (2000). Zachowanie młodzieży jako znak czasów, Kwartalnik Pedagogiczny, 183, nr 1, s. 3.

Springer, S. (2000). Przyczyny powstawania nowych ruchów religijnych we wspótczesnej Europie. W: Z. Stachowski (red.), Nowe ruchy religijne. Wybrane problemy, Warszawa-Tyczyn 2000, s. 37-45.

Szczepkowski J. (2007). Terapia mtodzieży z problemem narkotykowym, Toruń 2007. Szostak, M. (2001). Sekty destrukcyjne. Studium metodologiczno-kryminalistyczne, Zakamycze.

Szymańska, J. (2000). Programy profilaktyczne. Podstawy profesjonalnej psychoprofilaktyki, Warszawa.

Taran, M. (2000). Socjopsychologiczne uwarunkowania podatności na manipulacje w sektach. W: Kulty i sekty. Zagrożenia i profilaktyka. Ogólnopolska konferencja szkoleniowa, Katowice, s. 104-109.

Ward, D., (2000). "Where do I start?": Assessment and intervention with ex-cult members, Australian Social Work, 53:2, 37-42.

Wilson, B.R. (1961). Sects and Society. A Sociological Study of three Religious Groups in Britain, London.

Zwoliński, A. (2004). Anatomia sekty, Radom.

Zwoliński, A. (2005). Drogami sekt, Radom. 


\title{
Youth and Contemporary Controversial Cults: Selected Issues
}

\begin{abstract}
The paper addresses a very important issue of controversial cults and their impact on youth. The first part describes and analyzes youth as an crucial stage in human development, the social situation in which young people grow up. There are also analyzed the most important needs of young people.

The next part of the article presents the basic definitions of sects and discusses the manner of their controversial impact on society and youth. Then, the reasons for the emergence of sects are explained, as well as variables conducive to their possible attractiveness. The issue of susceptibility of children and youth to sects is also explained.

The final part focuses on the effects of assistance offered to young people. It is pointed out that it is necessary to organize and conduct preventive and therapeutic interactions in the context of the work of educators, social workers and psychologists.
\end{abstract}

Keywords: youth, sects, cults, prevention, therapy, society 